\title{
Járdány Krisztián
}

\section{Borászati üzemfejlesztési támogatások területi megoszlásának vizsgálata Magyarországon 2014-2020 között}

Jelen tanulmány az Európai Unió 2014-2020 közti költségvetési idöszakának ideje alatt a magyar borvidékekbe áramlott borászati üzemfejlesztési támogatások területi megoszlását vizsgálja. Az európai törekvésekkel összhangban a magyar szakpolitikai is ösztönzi a borászati ágazat fejlesztését, és a világpiaci versenyképesség megörzésére a minél magasabb minőségü borok kibocsájtását. Magyarország 6 borrégiója 22 borvidékének erőforrás-ellátottsága változatos képet mutat, mely alapján feltételezhetö, hogy a fejlesztési projektek tekintetében is jelentös területi különbségek nyilvánulnak meg. Az egyenlötlenségek feltárására szekunder forrásokból nyert adatok vizsgálatára támaszkodtam. A támogatások mértékét és eloszlását összevetettem a témában releváns fontosabb borászati és társadalmi mutatókkal. Eredményeim ismertetéséhez területi egyenlötlenségi mutatók használata mellett területi autokorrelációs vizsgálatot végeztem. Az alkalmazott módszertannal rámutattam a borászati ágazat fejlesztésével kapcsolatos centrumperiféria viszonyokra, és a 2014-2020 közti programozási periódus föbb szakágazati fejlesztési zónáira.

Kulcsszavak: borrégió, borvidék, borászati üzemek támogatása, területi elemzés JEL-kód: R12, R19

https://doi.org/10.32976/stratfuz.2021.20

\section{Bevezetés}

Az európai emberek borfogyasztási kultúrája hosszú évszázadokra visszavezethető (Kispál, 2017), és e hagyomány mélyen beágyazódott hazánk kultúrkörébe is (Gál, 2020). Napjainkra a szőlö- és borágazat Magyarországon az agrárgazdaság egyik fontos tényezőjévé nőtte ki magát, tekintve, hogy a magyar mezőgazdaság bruttó nemzeti össztermékéböl 2,6\%-kal részesedik (KSH, 2017).

Magyarországon jelenleg 6 borrégió 22 borvidéken folyik szőlőművelés azzal, hogy ezeket a szakpolitikai területi lehatárolásokat törvényi szinten szabályozzák.

A borvidéki területi lehatárolásról a 2004. évi XVIII. törvény a következök szerint rendelkezik: „olyan termőhelyek összessége, amely több település közigazgatási területére kiterjedően hasonló éghajlati, domborzati, talajtani adottságokkal, jellemző fajtaösszetételü és müvelésü ültetvényekkel, sajátos szőlő- és bortermelési hagyományokkal rendelkezik, és amelyről sajátos jellegü borászati termékek származnak.” E jogszabály értelmében borvidékbe olyan település sorolható, melynek a szőlő termőhelyi kataszterében nyilvántartott területe a település összes mezőgazdaságilag hasznosított területének 7\%-át eléri, illetve - a szakminiszter mérlegelése alapján - olyan település vagy településrész, amelyben hagyományosan borfeldolgozással foglalkozó bor adóraktár müködik. Ezek alapján a borvidékek méretükben, elhelyezkedésükben, és boraik karakterében is jelentősen különböznek egymástól (Molnár, 2007). A borrégió a 2012. évi CCXIX. törvény 4 . § e) pontja alapján ,a borvidékek közös érdekeik előmozdítására, valamint az általuk elöállított termékek származás-, minőség- és eredetvédelmére létrehozott olyan önkéntes társulás, amely hasonló szőlő- és bortermelési hagyományokkal rendelkező, földrajzilag egymáshoz közel eső vagy határos borvidékek összességéből áll”.

A Hegyközségek Nemzeti Tanácsának (HNT) statisztikai adatai szerint hazánk borvidékeinek összes szőlővel beültetett területe 2014-2020 közti hét év átlagában 64395 hektárt tett ki, melyből átlagosan 91,62\% volt termő ültetvény. A szüretel szőlőmennyiség átlaga közel 4 millió mázsa, míg az abból készült bor átlagos mennyisége 2,67 millió hektoliter. Gál (2020) a HNT adataira támaszkodva dolgozatában kiemeli, hogy Magyarország borvidékein mindösszesen 41,5 ezer regisztrált szőlőtermelő müködik, és az általuk megtermelt alapanyagot feldolgozó borászati 
szegmens fragmentált, és a belföldi borpiacon kiélezett versenyhelyzet tapasztalható. Megállapítja, hogy a borászati üzemek nagyobb része (a 2018/2019. borpiaci évben mintegy 59\%a) nem kínálja termékeit közvetlenül a fogyasztói piacon, hanem más borászatnak értékesíti azokat alapanyagként. Ezek mellett borpiaci dekoncentrációról számol be még annak ellenére is, hogy a hazánkban elöállított összes bor 66,5\%-át 25 borászati üzem hozta forgalomba a 2018/19-es borpiaci évben. A magyar borpiac sajátosságait elemezve összefoglalóan megállapítja, hogy ,a kínálat széttöredezett, a piac a vertikum minden részében erősen versenyző’”, továbbá, hogy „olyan ágazat képe rajzolódik ki, amely alapvetően jónak mondható termőhelyi adottságok mellett alacsony hozzáadott értékü termékeket készít, alacsony hatékonysággal”.

Véleményem szerint a jó termőhelyi adottságok mellett a megfelelő színvonalú borkészítési technológiával és borkészítési kultúrával rendelkező területeken a borászati ágazat jelenléte komoly endogén erőforrás lehet. Ez nagyrészt annak köszönhető, hogy a szűken vett szőlészeti és borászati tevékenység sikeressége komoly hatást fejt ki a részben vagy egészében rá épülő (pl.: gasztronómia, turizmus, kereskedelem), vagy támogató szektorokra (pl.: technológia, kutatás stb.), és ezek hozadéka számottevően a rurális térségek gazdaságában jelentkezik. A borászati ágazatban rejlö, még kiaknázatlan potenciálok fejlesztése azok multiplikátor hatása miatt meghatározók lehetnek az e tevékenységgel érintett területek helyi-, illetve regionális gazdaságfejlesztési folyamataiban és stratégiájában, valamint a hosszú távon jövedelmezőbb gazdaságszerkezetük kialakításában. (Járdány és Duray, 2020).

A területi egységek gazdasági fejlődése és struktúrája oda-vissza hatnak egymásra. A gazdasági szerkezet tudatos alakításával gyorsítható vagy lassítható a gazdasági növekedés üteme, és ezen keresztül a gazdaság fejlettsége (Stark, 2004). Nemes-Nagy (2005) a gazdasági fejlődés és a növekedés közt abban látja a különbséget, hogy míg a növekedésben a mértékek, addig a fejlődésben pedig az értékek változnak. Az adott területi egységen belül az ágazati struktúra átalakítása leginkább akkor lehet letéteménye egy jól prosperáló gazdaságszerkezetnek, ha megfelelő arányú az ehhez rendelt erőforrások kvantitatív és kvalitatív aspektusú allokációja. Alapvető kérdés, hogy az ágazatok termelékenységének térbeli különbségei befolyásolással vannak-e a területi egyenlőtlenségek változására és újratermelésére.

Az ágazati politikák eltérő időtávon érvényesülö, a társadalmi és gazdasági folyamatokba tartósan beágyazódó jelenség-sorozatokat indukálhatnak, amelyek térspecifikus jellemzőkkel rendelkeznek. Az ágazati politikák sokszor különbözö indíttatásúak, emiatt ellentmondásosak is. Ezek a döntéssorozatok együttesen befolyásolják egy-egy terület gazdasági növekedését, fejlődését és az ott élők életminőségének a változását. A növekedés és a fejlödés térben egyenetlen, mivel a feltételrendszerek és a hatótényezők a tér minden pontján eltérőek (Enyedi, 2004).

Lőrincz (2016) kiemeli, hogy Magyarországon az ágazati szakpolitikák bár rendelkeznek területi aspektussal, de alapvetően ágazati és nem regionális célokat mentén valósulnak meg, miközben az ágazati döntések nagymértékben hatnak az egyes területi egységek társadalmi és gazdasági folyamataira. Keszthelyi (2019) dolgozatában tovább szükíti a gondolatot. Véleménye szerint az ágazati döntésekhez rendelhető különböző, megfelelően allokált állami intervenciók vállalkozások szintjén történő megjelenése adott területi egységen számos pozitív extern hatást fejt ki (pl.: adóbevételek növekedése, munkahelyteremtés, innovációk elterjedése, tudástranszfer). E mellett felhívja a figyelmet, hogy a szabadpiac szereplői ezeket a pozitív társadalmi és gazdasági extern hatásokat döntéseik során jellemzően nem veszik figyelembe. Sok esetben állami intervenció nélkül a kibocsátás az optimálisnál előnytelenebb a társadalom szempontjából.

Az ágazatfejlesztések, és ezekből kiinduló területfejlesztési beavatkozások - a térségi erőforrások oldaláról - két alapvető megközelítésben tervezhetők. Az egyik esetben a hiányzó erőforrásokat kívülről pótoljuk, vagyis jelentős támogatásokat adunk az ottani fejlesztésekhez. A másik esetben arra törekszünk, hogy feltárjuk a térség saját erőforrásait, és ezeket az erőforrásokat próbáljuk minél hatékonyabban hasznosítani, „képessé téve” erre a helyi szereplőket. A helyes megoldás e két logikának az adott térség számára optimális ötvözetének alkalmazása (Juhász, 2020). 
A magyar borászoknak ugyanazokkal a nehézségekkel kell megbirkózniuk, mint az Európai Uniós társaiknak, elsősorban az állandóan jelentkező értékesítési nehézségekkel, az erősödő piaci versennyel, és a strukturális bortúltermelési válsággal. Az ágazat szereplöit ez mindenképpen arra sarkallja, hogy magasabb hozzáadott értékü, megfelelő ár/érték arányú, nagy mennyiségben is eladható borokkal jelenjenek meg a nagy mennyiségeket igénylő piaci csatornákat megcélozva (Sidlovits, 2008).

Számos tanulmány rámutatott, hogy a borászati termékek piacán a termékek ára mellett jelentős tényező a borok minősége. Az élelmiszeripari termékek minőségének fejlesztését az Európai Unió Közös Agrár Politikája (KAP) is ösztönzi annak 1992-es reformja óta (Meloni és Swinnen, 2013). A borminőséget számos tényező befolyásolja: a termőhelyi viszonyok, a fajta, az évjárat, az alkalmazott szőlészeti és borászati technológia, valamint a bort elkészítő ember szakértelme.

A borminőségre ható tényezők közül a rendelkezésre álló magas minőségü, korszerü borászati technológia lehetővé teszi a borászatból származó fajlagos jövedelem növelését, a hatékonyság fokozását, a környezetre gyakorolt káros hatások mérséklését, és alkalmazása révén fenntartható módon növeli a piaci biztonságot (Magda és Gergely, 2004).

A technológiai innováció forráshiány miatt sokszor csak támogatással valósulhat meg. A magyar agrárpolitika támogatási rendszerében az uniós csatlakozást megelőzően is fellelhetőek voltak a beruházási támogatások (Losoncz, 2004) azzal, hogy Hajdú (2021) tanulmányában kiemeli, miszerint az Európai Uniós támogatások koncentráltsága elsősorban a sürün lakott csomóponti területeken figyelhető meg.

A vidékfejlesztési politika végrehajtása a tagállamok (vagy régióik) által kijelölt vidékfejlesztési programokon keresztül történik. A többéves programok egy adott egyedi területre szabott stratégiát követnek, megfelelve a tagállamok (vagy régiók) sajátos igényeinek (KAP).

Az Európai Unió 2014-2020 költségvetési időszakában a hazai szőlészeti és borászati szektorba áramló vidékfejlesztési programok keretében nyújtott támogatások esetén fontos tényező volt, hogy a különböző források (ezen belül a pályázati források) mennyiben tudnak hozzájárulni a valós fejlődéshez és a gazdadasági-társadalmi jóléthez. A vidékfejlesztési programokból származó források elosztása a következő prioritások mentén valósul meg:

1. a tudásátadás előmozdítása a mezőgazdaságban, az erdészetben és a vidéki térségekben;

2. a versenyképesség fokozása a mezőgazdasági termelés valamennyi típusa esetében és a mezőgazdasági üzemek életképességének javítása;

3. az élelmiszerlánc szervezésének és a kockázatkezelésnek a mezőgazdaság terén történő előmozdítása;

4. a mezőgazdaságtól és az erdészettől függő ökoszisztémák állapotának helyreállítása, megőrzése és javítása;

5. az erőforrás-hatékonyság előmozdítása, valamint az alacsony szén-dioxid kibocsátású és az éghajlatváltozáshoz alkalmazkodni képes gazdaság irányába történő elmozdulás támogatása a mezőgazdasági, az élelmiszer-ipari és az erdészeti ágazatban;

6. a társadalmi befogadás előmozdítása, a szegénység csökkentése és a gazdasági fejlődés támogatása a vidéki térségekben (Keszthelyi, 2019).

A borászati szektor technológiai fejlesztését mind az európai uniós, mind a hazai szakpolitika is ösztönzi, ezért az Európai Unió 2014-2020 között költségvetési időszakában a Magyar Államkincstár (MÁK) adatai szerint összesen 20,86 milliárd forint összegü borászati üzemfejlesztési támogatást kaptak maximálisan $50 \%$ támogatási intenzitás mellett a 22 borvidéken müködő magyar borászati üzemek. A támogatások a KAP Vidékfejlesztési Programjából (VP) kerültek finanszírozásra, szem előtt tartva a 1305/2013/EU rendelet 4. és 5. cikkében foglalt célkitüzéseket és prioritásokat. A támogatott tevékenységek két pillére:

1. Borászati gépek, technológiai berendezések beszerzése, építéssel járó fejlesztési beruházások támogatása. 
2. A borászati termékek értéknövelésével összefüggő, a környezeti erőforráshatékonyságot célzó fejlesztések támogatása.

Kutatásom témájával összefüggésben fontos megemlíteni, hogy a hazai szőlő- és borpiaci ágazat támogatási rendszere - összhangban az EU törekvéseivel és joganyagával -priorizálja a versenyképes minőségi átalakítást. Kutatásom célja a magyar borvidékre 2014-2020 közt áramlott borászati üzemfejlesztési támogatások területi megoszlásának vizsgálata és regionális aspektusú elemzése.

\section{Anyag és módszer}

Alapvetően szekunder források elemzésére támaszkodtam, melynek megalapozására a témakörben elérhető hazai és nemzetközi szakkönyveket, doktori értekezéseket, és folyóirat cikkeket tekintettem át. Ezek feldolgozását követően a Területfejlesztési és Területrendezési Információs Rendszer (TeIR), a Hegyközségek Nemzeti Tanácsa (HNT), a Pest Megyei Kormányhivatal (PMKH), és a Magyar Államkincstár (MÁK) vonatkozó adatait tekintettem át, és dolgoztam fel. Az elemzést Magyarország borvidéki lehatárolási területein belül végeztem. A támogatással, és a borvidékek társadalmi térszerkezetével kapcsolatos adatok települési szinten, a szőlészeti és borászati adatok pedig borvidéki szinten álltak rendelkezésemre.

Egyes nyers adatok, valamint a számított ért különböző szintű területi egyenlőtlenségeinek kimutatására Duál-mutatót, és Hoover-indexet alkalmaztam. Ezen egyenlőtlenségi mutatók a területi különbségek mértékét az adatok területi elhelyezkedésétől függetlenül határozzák meg. A Duál-mutató a teljes megoszlás átlaga feletti értékek átlagának és a teljes megoszlás átlaga alatti értékek átlagának a hányadosa. Képlete:

$$
\mathrm{D}=\frac{x_{a}}{x_{m}}
$$

ahol: az $\bar{x}$ az $\mathrm{x}_{\mathrm{i}}$ számtani átlaga, az $\mathrm{x}_{\mathrm{a}} \bar{x}$-nál nagyobb $\mathrm{x}_{\mathrm{i}}$ értékek számtani átlaga, az $\mathrm{x}_{\mathrm{m}} \mathrm{az} \bar{x}$-nál kisebb $x_{\mathrm{i}}$ értékek számtani átlaga.

Akkor beszélhetünk területi egyenlőségröl, ha a mutató értéke 1, ennél nagyobb érték esetén az index azt az ollót mutatja, amely az átlagosan nagyobb értékkel bíró és átlagosan kisebb értékkel rendelkezö területegységek között fennáll (Tóth és Káposzta, 2014).

A Hoover-index gyakran alkalmazott eloszlás-típusú jelzőszám (Kiss - Németh, 2006). A számításhoz használt képlet:

$$
h=\frac{\sum_{i=1}^{n}\left|x_{i}-f_{i}\right|}{2}
$$

ahol: $\mathrm{x}_{\mathrm{i}}$ és $\mathrm{f}_{\mathrm{i}}$ a két megoszlási viszonyszám, melyekre igaz, hogy $\sum x_{i}=100$ és $\sum f_{i}=100 \mathrm{Az}$ index azt mutatja meg, hogy az egyik ismérv hány százalékát kell a területegységek között átcsoportosítani, hogy a területi megoszlása a másik jellemzőével azonos legyen.

A Hoover-index értékkészlete: $0 \leq \mathrm{H} \leq 100$ (Ács és Pongrác, 2008). Az index minél magasabb értéket vesz fel, annál nagyobb a vizsgált mutató tekintetében a területi polarizáltság.

A borászati üzemfejlesztési támogatások adatait, és a rendelkezésre álló társadalmi térszerkezeti, illetve szőlészeti és borászati statisztikai adatokat korrelációvizsgálatnak vetettem alá. Az összefüggések feltárására Pearson-féle korrelációs koefficienst számítottam. A Pearson-féle korreláció egy lineáris statisztika, tehát olyan adatsorokon ad megbízható értéket, ahol a két változó közötti kapcsolat egy egyenessel leírható. A korreláció vizsgálat eredményét a kiugró értékek (outlier pontok) erősen befolyásolják. A koefficiens értéke +1 és -1 közötti értéket vehet fel. Minél közelebb áll az együttható abszolút értéke az 1-hez, annál szorosabb a kapcsolat. Az 
együttható abszolút értékben 0,7-1 intervallumon erős; 0,3-0,7 intervallumon közepes; és 0-0,3 intervallumon gyenge korrelációt jelez (Nemes Nagy, 2005). Amennyiben a korrelációs együttható elöjele pozitív, akkor a két változó között egyenes, ellenkező esetben fordított arányosság áll fenn. Ha nincs korreláltság $(\mathrm{r}=0)$ a két változó nem feltétlenül független, de az biztos, hogy nincs köztük lineáris típusú összefüggés (Győri és Egri, 2020) A kapott koefficienseket hipotézisvizsgálatnak vetettem alá az eredmények szignifikanciavizsgálatának érdekében.

Egyes települési szinten rendelkezésre álló támogatásokkal kapcsolatos nyers adatok és számított fajlagos mutatók vonatkozásában területi autokorrelációs analízist (Hot Spot elemzést) végeztem Getis-Ord féle lokális $\mathrm{G}_{\mathrm{i}}{ }^{*}$ statisztika (Getis és Getis, 1996) alkalmazásával, térbeli csoportosulások meghatározására. A lokális megközelítés a térbeli struktúrák helyi sajátosságait tárja fel. Az alapfelvetés (nullhipotézis) szerint nincs területi autokorreláció a vizsgált változók között, azok térbeli elrendeződése véletlenszerü. A lokális $\mathrm{G}_{\mathrm{i}}{ }^{*}$ statisztika a súlyozott térbeli pontok koncentrációjával azonosítja a térbeli asszociáció erősségét (Tóth, 2014). A számított értékek standardizálásával megkapott $Z$ érték minél magasabb, annál intenzívebb a magas értékek csoportosulása. Az adott távolságon belüli átlag feletti értékek tömörülése esetén a $\mathrm{G}_{\mathrm{i}}$ értéke magas lesz, az alacsony értékek koncentrációja esetén alacsony. A statisztika szimmetrikus térbeli súlymátrixot tartalmaz, melynek elemei bináris $(0,1)$ értékeket vehetnek fel. A meghatározott (d) távolságon belüli elemek értéke 1, minden más esetben 0 érték szerepel. A mutató ezen típusa szerint az adott lokáció önmagával szomszédos, a súlymátrixban szereplő érték 1. A Getis-Ord statisztika lokális változata az alábbi képlettel számítható:

$$
G_{i}(d)=\frac{\sum_{j=1}^{n} w_{i j}(d) x_{j}}{\sum_{j=1}^{n} x_{j}}
$$

ahol: $\mathrm{w}_{\mathrm{ij}}$ a szimmetrikus térbeli súlymátrix, $\mathrm{d}$ a távolság, $\mathrm{x}$ a területi ismérv és igaz az, hogy $\mathrm{i}=\mathrm{j}$.

Tanulmányomban a szomszédsági kapcsolatok operacionalizálásához sorstandardizált „királynő” súlymátrixokat alkalmaztam. A hipotézisvizsgálat szignifikancia-szintjét $\mathrm{p}=0,1$ értékben határoztam meg. Az eredményeket poligon kartogramokon ábrázoltam a feltárt forrópontok dozimetrikus kiterjedtségének szemléltetésére.

A területi statisztikai elemzéseket és az eredmények kartogramokon történő megjelenítését IBM SPSS v26 statisztikai program, illetve ArcGIS 10.8. térinformatikai szoftver segítségével végeztem el.

\section{Eredmények}

Magyarország hat borrégiójának 22 borvidékén mindösszesen 625 település található, mely az összes magyarországi település 19,81\%-a. 2019-ben hazánk lakónépességének 28,23\%-a élt borvidéki településeken, szám szerint 2.758.312 fö. A borvidékekbe - és így borrégiókba - tartozó települések együttes területe (bruttó területe) $25410,45 \mathrm{~km}^{2}$, ami Magyarország teljes területének 27,32\%-a. A HNT adatai alapján a 2015-2019 közti öt év átlagában a borvidékekbe tartozó termő borszőlőterületek 59467,4 hektáron terültek el, így az összes bruttó borvidéki területből 2,34\%kal részesedtek. A borszőlő-ültetvényekről származó termést a PMKH adatai szerint a vizsgált időszakban borvidéki szinten mindösszesen 7019 darab borelőállítási-engedéllyel rendelkező borászati üzem (1. ábra) dolgozta fel, melyek ezen időszak alatt átlagosan mindösszesen 2958477,2 hektoliter bort állítottak elö éves szinten. 


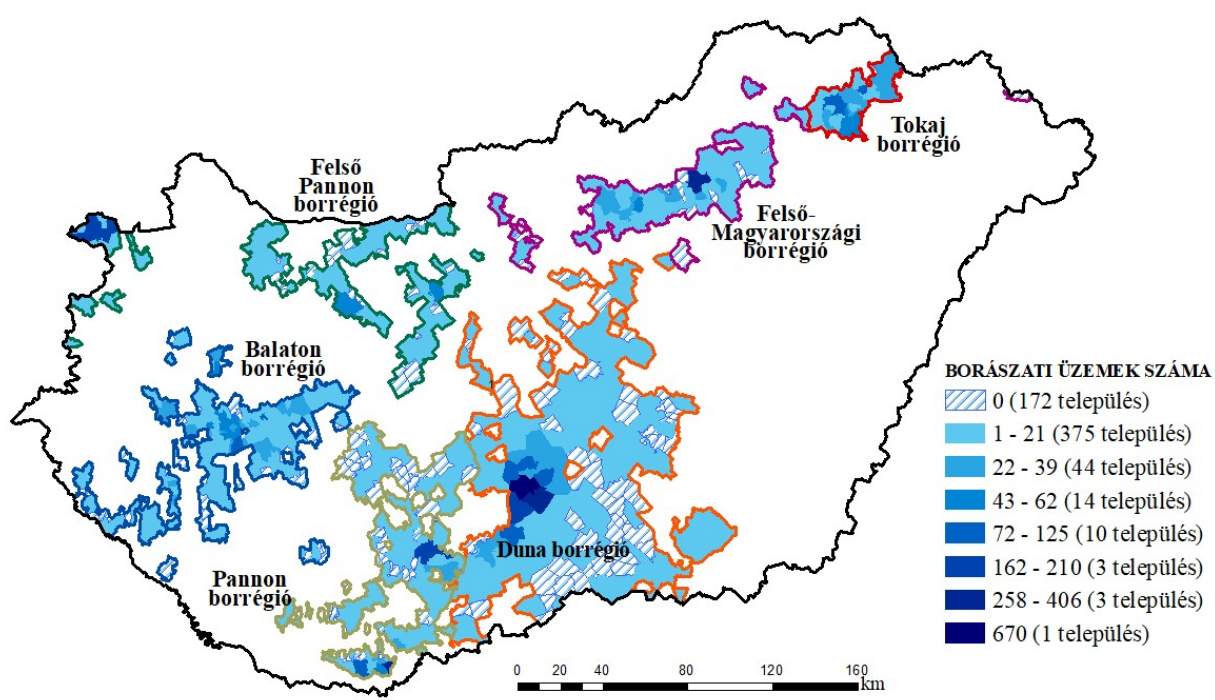

1. ábra: Magyarországi borászati üzemek számának területi megoszlása borrégiónként, 2020

Figure 1: Territorial distribution of the number of wineries in Hungary by wine region, 2020

Forrás: www.kormanyhivatal.hu adatok alapján saját szerkesztés

A borvidékek településeire a 2014-2020 közti EU-s programozási időszakban a MÁK közzétételi listája szerint mindösszesen 20,859 milliárd forint borászati üzemfejlesztési támogatás került kifizetésre. A legnagyobb összeggel támogatott borrégió a Pannon borrégió volt 6514,8 millió forint $(\mathrm{MFt})$ összeggel. Borvidéki szinten a Pannon borrégióban található Szekszárdi borvidék részesült a legtöbb támogatásban, melynek összege 3186,6 MFt volt, és ezzel az őt befogadó borrégió összes támogatásának 48,9\%-át, míg az összes borvidéki borászati üzemfejlesztési támogatás 15,3\%-át nyerte el. A legkevesebb támogatást a Felső-Pannon borrégió kapta 1613,7 MFt összegben, míg borvidéki szinten a Csongrádi borvidék az utolsó a maga 2,1 MFt támogatásával.

Borvidéki lehatárolási szinten a borászati üzemek fejlesztésére megítélt átlagtámogatás összege 948,2 MFt/borvidék volt. Ezen érték felett 5 borvidék részesült támogatásban (Tokaji, Szekszárdi, Kunsági, Egri, Villányi). A Balatonboglári és Balatonfüred-Csopaki borvidékek borászati üzemeinek a támogatási értéke csaknem eléri az átlagos szintet, mindazonáltal összességében 17 borvidék átlag alatt szerepelt. A támogatások borvidékek közötti arányait tekintve a Tokaji borvidék részesült a legnagyobb arányban a támogatásokból a maga 16,05\%-os részesedésével, míg 4 borvidék kevesebb, mint 1\%-os arányban részesedett: Balaton-felvidéki borvidék $(0,84 \%)$, Soproni borvidék $(0,69 \%)$, Zalai borvidék $(0,37 \%)$, valamint a Csongrádi borvidék $(0,01 \%)(2$. ábra). 


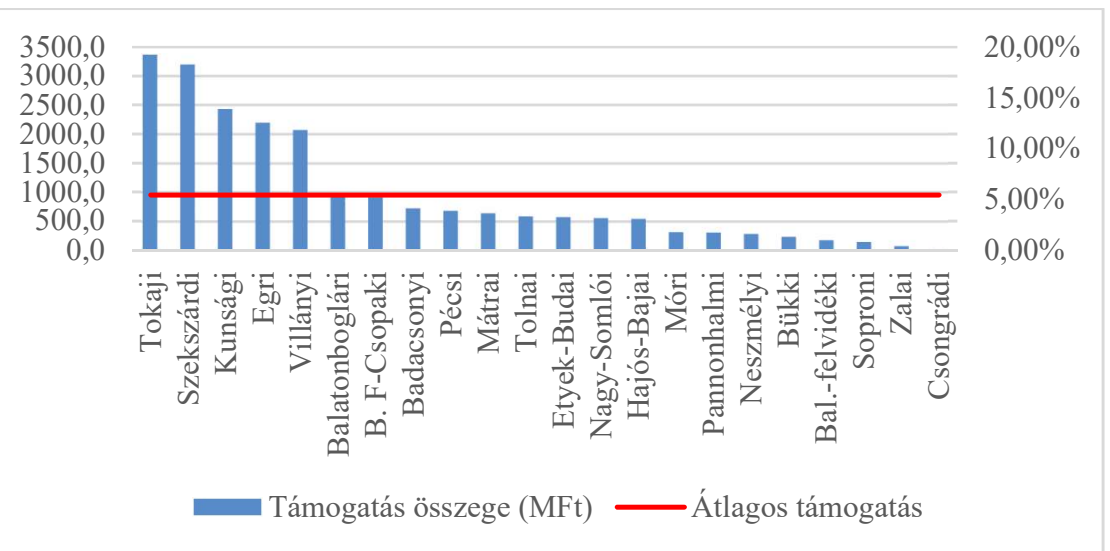

2. ábra: Borászati üzemfejlesztési támogatások borvidékenként (2014-2020)

Figure 2: Winery development subsidies by wine region (2014-2020)

Forrás: Magyar Államkincstár adatai alapján

A szőlészeti-borászati területi lehatárolások igen eltérő képet mutatnak minden vizsgált társadalmi térszerkezeti mutató, és szőlészeti-borászati változó tekintetében (1. táblázat).

1. táblázat: A tanulmányban szereplö vizsgálatok alapadatai

Table 1: Basic data from the studies included in the study

\begin{tabular}{|c|c|c|c|c|c|c|c|}
\hline Borrégió & Borvidék & $\begin{array}{l}\text { Projekt } \\
\text { (db) }\end{array}$ & $\begin{array}{l}\text { Támogatás } \\
\text { (millió Ft) }\end{array}$ & $\begin{array}{l}\text { Bruttó } \\
\text { terület } \\
\left(\mathrm{km}^{2}\right)\end{array}$ & $\begin{array}{l}\begin{array}{c}\text { Átlagos } \\
\text { hozam }\end{array} \\
\text { 2014-2019 } \\
\text { (hl bor) }\end{array}$ & $\begin{array}{l}\text { Lakó- } \\
\text { népesség } \\
\text { (fö) }\end{array}$ & $\begin{array}{c}\text { Bort } \\
\text { előállító } \\
\text { borászati } \\
\text { üzemszám } \\
\text { (db) }\end{array}$ \\
\hline \multirow{6}{*}{$\begin{array}{l}\text { Balaton } \\
\text { borrégió }\end{array}$} & Badacsonyi & 58 & 721,4 & 274,4 & 82151,6 & 24160 & 485 \\
\hline & Balatonboglári & 70 & 926,6 & 1195,3 & 156805 & 64493 & 169 \\
\hline & Balaton-felvidéki & 39 & 175,0 & 494,9 & 18910,4 & 34154 & 322 \\
\hline & $\begin{array}{l}\text { Balatonfüred- } \\
\text { Csopaki }\end{array}$ & 72 & 912,4 & 507,7 & 47682,6 & 40387 & 389 \\
\hline & Nagy-Somlói & 34 & 552,6 & 167,7 & 8393,4 & 13868 & 141 \\
\hline & Zalai & 19 & 76,6 & 922,5 & 26451,2 & 84241 & 186 \\
\hline \multicolumn{2}{|c|}{ Balaton borrégió } & 292 & 3364,6 & 3562,6 & 327885,2 & 261303 & 1692 \\
\hline \multirow{3}{*}{$\begin{array}{c}\text { Duna } \\
\text { borrégió }\end{array}$} & Csongrádi & 1 & 2,1 & 1899,2 & 14166 & 271557 & 45 \\
\hline & Hajós-Bajai & 26 & 540,9 & 1085,7 & 66412,2 & 64749 & 168 \\
\hline & Kunsági & 185 & 2427,0 & 8246,3 & 1390843,6 & 665629 & 1917 \\
\hline \multicolumn{2}{|c|}{ Duna borrégió } & 212 & 2970,0 & 11231,2 & 1471421,8 & 1001935 & 2130 \\
\hline \multirow{5}{*}{$\begin{array}{l}\text { Felső } \\
\text { Pannon } \\
\text { borrégió }\end{array}$} & Etyek-Budai & 46 & 568,7 & 939,3 & 93116,8 & 129426 & 120 \\
\hline & Móri & 20 & 311,3 & 250,3 & 10779 & 21899 & 70 \\
\hline & Neszmélyi & 17 & 285,1 & 888,3 & 26451,2 & 111441 & 83 \\
\hline & Pannonhalmi & 30 & 305,2 & 502,3 & 15526,8 & 165170 & 58 \\
\hline & Soproni & 51 & 143,3 & 506,6 & 43950,8 & 99607 & 288 \\
\hline \multicolumn{2}{|c|}{ Felső Pannon borrégió } & 164 & 1613,7 & 3086,9 & 189824,6 & 527543 & 619 \\
\hline \multirow{3}{*}{$\begin{array}{l}\text { Felső Mo.-i } \\
\text { borrégió }\end{array}$} & Bükki & 22 & 231,1 & 1048,8 & 20339,4 & 219393 & 96 \\
\hline & Egri & 99 & 2185,6 & 569,2 & 242043,6 & 82634 & 385 \\
\hline & Mátrai & 49 & 631,8 & 1174,1 & 215479,4 & 197100 & 245 \\
\hline
\end{tabular}




\begin{tabular}{|l|l|c|c|c|c|c|c|}
\hline \multicolumn{2}{|l|}{$\begin{array}{l}\text { Felső-Magyarországi } \\
\text { borrégió }\end{array}$} & $\mathbf{1 7 0}$ & $\mathbf{3 0 4 8 , 5}$ & $\mathbf{2 7 9 2 , 1}$ & $\mathbf{4 7 7 8 6 2 , 4}$ & $\mathbf{4 9 9 1 2 7}$ & $\mathbf{7 2 6}$ \\
\hline \multirow{3}{*}{$\begin{array}{c}\text { Pannon } \\
\text { borrégió }\end{array}$} & Pécsi & 40 & 679,2 & 847,6 & 14666,4 & 202135 & 150 \\
\cline { 2 - 8 } & Szekszárdi & 194 & 3186,6 & 622,1 & 96851,2 & 55121 & 322 \\
\cline { 2 - 8 } & Tolnai & 62 & 586,2 & 2120,8 & 101503,6 & 117179 & 120 \\
\cline { 2 - 8 } & Villányi & 141 & 2062,8 & 273,7 & 105887 & 21691 & 522 \\
\hline Pannon borrégió & $\mathbf{4 3 7}$ & $\mathbf{6 5 1 4 , 8}$ & $\mathbf{3 8 6 4 , 3}$ & $\mathbf{3 1 8 9 0 8 , 2}$ & $\mathbf{3 9 6 1 2 6}$ & $\mathbf{1 1 1 4}$ \\
\hline \multicolumn{2}{|l|}{ Tokaj borrégió } & $\mathbf{2 9 1}$ & $\mathbf{3 3 4 7 , 8}$ & $\mathbf{8 7 3 , 5}$ & $\mathbf{1 7 2 5 7 5}$ & $\mathbf{6 6 5 6 2}$ & $\mathbf{7 3 8}$ \\
\hline \multicolumn{2}{|l|}{ Mindösszesen } & $\mathbf{1 5 6 6}$ & $\mathbf{2 0 8 5 9 , 3}$ & $\mathbf{2 5 4 1 0 , 5}$ & $\mathbf{2 9 5 8 4 7 7 , 2}$ & $\mathbf{2 7 5 2 5 9 6}$ & $\mathbf{7 0 1 9}$ \\
\hline
\end{tabular}

Forrás: saját készités www.kormanyhivatal.hu, www.hnt.hu, és www.teir.hu adatok alapján

Az 1. táblázatban szereplő borvidéki adatok összefüggésvizsgálatának eredménye szerint a támogatási összeg és a megítélt projektek darabszáma közt szoros $(\mathrm{r}=0,951)$, a támogatási összeg és a borászati üzemszámok között közepes $(\mathrm{r}=0,599)$ összefüggés figyelhető meg $\mathrm{p}=0,01$ szignifikancia szinten. E mellett a támogatási összeg és az átlagos borhozam között van közepes korreláció $(\mathrm{r}=0,456)$, ez azonban csak $\mathrm{p}=0,05$ szinten szignifikáns. A támogatások tekintetében e három kapcsolaton kívül minden egyéb esetben elfogadtam a nullhipotézist.

Az adott borvidéken belül támogatott projektek számát összevetve az adott borvidéken müködő összes borászati üzem számával megállapítható, hogy az országos átlag 0,22 projekt/borászati üzem. E tekintetben a listavezető a Szekszárdi borvidék 0,58 projekt/borászati üzem értékkel. tehát itt a borászati üzemek több, mint fele volt érintett borászati üzemfejlesztésben. 0,5-ös érték feletti adattal még két borvidéken találkozhatunk, a Tolnai borvidéken, és a Pannonhalmi borvidéken. Az átlag felett összesen 12, az átlag alatt pedig 10 borvidék értékei szerepelnek. A sereghajtók a Zalai borvidék $(0,099)$, a Kunsági borvidék $(0,094)$ és a Csongrádi borvidék $(0,022)$.

Az egy projektre jutó átlagos támogatás értéke 12,32 MFt/projekt értéket vett fel. $20 \mathrm{MFt} /$ projekt feletti érték két borvidéken jelentkezett, az Egri borvidéken 22,08 MFt/projekt, és a Hajós-Bajai borvidéken 20,80 MFt/projekt értékekkel. Átlag felett mindösszesen 13, míg átlag alatt 9 borvidék adatai szerepelnek.

A borvidékek bruttó területére eső támogatásokat tekintve az átlagtámogatás értéke $1,59 \mathrm{MFt} / \mathrm{km}^{2}$ értéket vett fel. E szempontból legkoncentráltabban a Villányi borvidék volt támogatott, 7,54 $\mathrm{MFt} / \mathrm{km}^{2}$ érték mellett. Átlag felett 7 borvidék szerepel e mutató tekintetében (a Villányi-, Szekszárdi-, Egri-, Tokaji-, Nagy-Somlói-, Badacsonyi-, és Balatonfüred-Csopaki borvidék). Meg kell jegyezni, hogy az átlag alatt szereplö 15 borvidék közül 14 borvidék még az $1 \mathrm{MFt} / \mathrm{km}^{2}$ szintet sem érte el.

A borvidéki szőlőterületek méretére eső borászati üzemfejlesztési támogatások átlagértéke 47,35 $\mathrm{MFt} / \mathrm{km}^{2}$ szőlöterület. A legmagasabb, 148,56 MFt/szőlőterület $\mathrm{km}^{2}$ érték a Szekszárdi borvidéken jelentkezett. Két további borvidék, a Pécsi és a Nagy-Somlói szerepelt még 100 $\mathrm{MFt} / \mathrm{km}^{2}$ felett. A legalacsonyabb érték a Csongrádi borvidéken mutatkozott $0,20 \mathrm{MFt} / \mathrm{km}^{2}$ adattal. Átlag felett 12, átlag alatt 10 borvidék szerepelt.

A borvidéken található borászati üzemek számára jutó átlagos támogatás értéke 3,35 $\mathrm{MFt}$ /borászati üzem. A borászati üzemekre jutó támogatási összeg éllovasa a Szekszárdi borvidék volt 9,49 MFt/borászati üzem értékkel. Átlag feletti érték 12, míg átlag alatti érték 10 borvidék esetén jelentkezett.

Az átlagos éves borhozamokra jutó támogatásokat figyelembe véve az egy liter borra jutó támogatás átlagos értéke 70,5 Ft. A borhozamra jutó legnagyobb támogatási érték a Nagy-Somlói borvidéken jelentkezett 658,4 Ft értékkel. A legkisebb érték a Csongrádi borvidéknél mutatkozott, ahol az egy liter borra jutó borászati üzemfejlesztési támogatás értéke elenyésző, mindössze 1,5 Ft (3. ábra). Átlagosnál magasabb értékeket 14 borvidék esetén figyelhetünk meg. E 14 borvidék közül 8 vonatkozásában a számított eredmény az átlagos érték több, mint kétszeresének értékét veszi fel. Borrégiós viszonylatban négy borrégió átlag feletti értéket vett fel, miközben a Felső- 
Magyarországi borrégió kicsivel (63,8 Ft/l), a Duna borrégió pedig lényegesen (20,2 Ft/l) elmaradt az átlagtól.

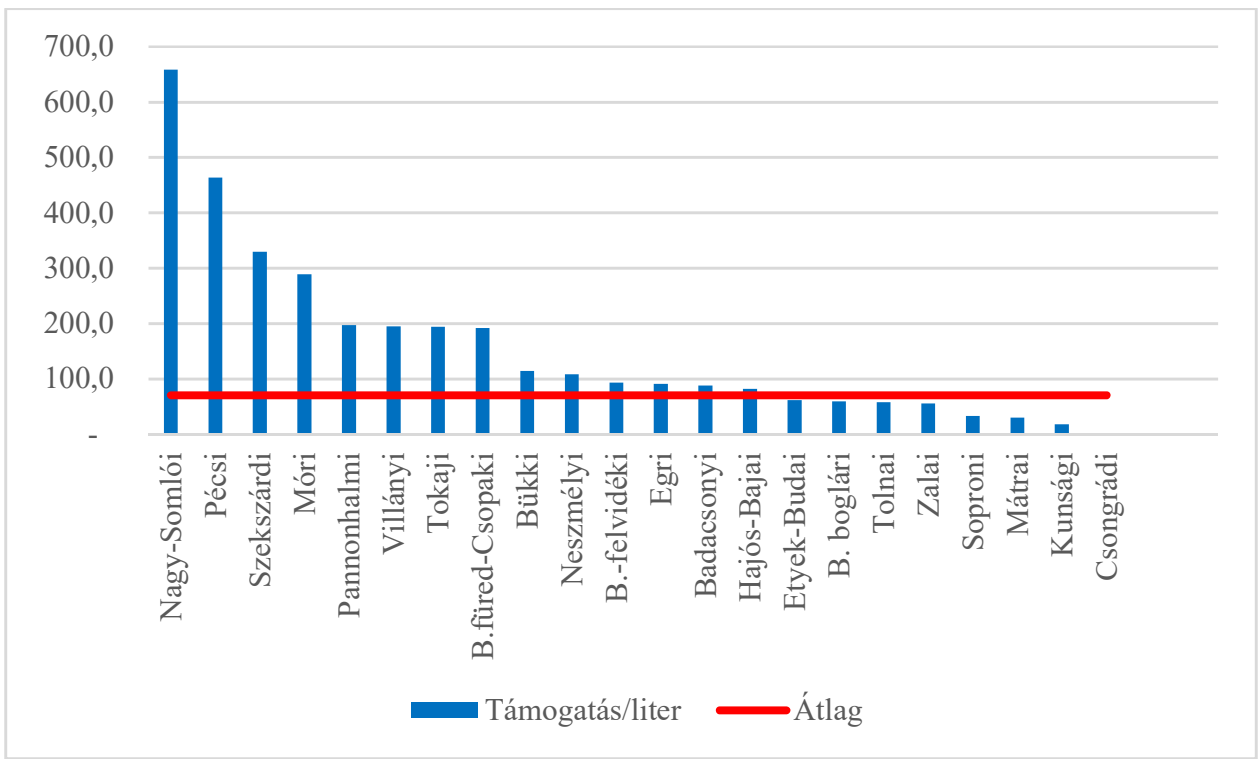

3. ábra: Atlagos borhozamra jutó támogatás borvidékenként 2014-2020 között (Ft/l)

Figure 3: Support per average wine yield, by wineland between 2014-2020 (HUF/l) Forrás: www.hnt.hu és www.mvh.allamkincstar.gov.hu adatok alapján saját számitás és szerkesztés

Az eddig bemutatott fajlagos értékek viszonylatában készített területi egyenlőtlenségi mutatókat a 2. számú táblázat tartalmazza.

2. táblázat: A támogatások fajlagos értékeinek területi egyenlötlenségi mutatói

Table 2: Territorial inequality indicators of the specific values of subsidies

\begin{tabular}{|l|c|c|}
\hline Mutató & Duál-mutató & Hoover-index \\
\hline Támogatás összege (MFt) & 5,87 & \\
\hline Támogatás (MFt)/elkészített bor (hl) & 4,96 & $42,9 \%$ \\
\hline Támogatás (MFt)/Projekt (db) & 2,10 & $10,25 \%$ \\
\hline Támogatás (MFt)/Bruttó terület $\left(\mathrm{km}^{2}\right)$ & 8,70 & $49,7 \%$ \\
\hline Támogatás (MFt)/Lakónépesség (fó) & 9,94 & $54,19 \%$ \\
\hline Támogatás (MFt)/Összes borászati üzem (db) & 3,50 & $30,9 \%$ \\
\hline
\end{tabular}

Forrás: saját számitás és szerkesztés

A borászati üzemfejlesztési támogatások polarizáltságának mértéke a borvidékek területén élő lakónépesség, és a bruttó terület tükrében a legmagasabb. Az egyenlötlenségi mutatók értékeinek és az összefüggés-vizsgálat eredményeinek komplex elemzésével következtethetünk arra, hogy a támogatások jellemzően a kevésbé sürün lakott rurális téregységekbe irányultak, illetve, hogy társadalmi hatásuk jellemzően lokális szinten nyilvánulhat meg. A borhozam viszonylatában vizsgált borvidéki támogatások esetén is magas polarizációt láthatunk. Ennek mértékét összevetve az alapadatok összefüggésvizsgálati eredményeivel arra következtethetünk, hogy a támogatások allokációjánál nem volt szempont a bor-kibocsájtás mennyiségi aspektusa. A borászati üzemekre 
jutó támogatási összeg területi egyenlőtlensége közepesnek mondható, de az összefüggésvizsgálati eredményekkel összevetve arra enged következtetni, hogy térbeli csoportosulások jelentkezhetnek e tekintetben. A támogatási összegeknek a projektszámokkal kapcsolatban számított egyenlőtlenségi mutatói egy kvázi kisimult térstruktúrát vetítenek elénk, mely magyarázata lehet, hogy a nyertes projektek támogatási maximumra törekedve nyújtották be pályázataikat.

A települési szinten is rendelkezésre álló adatok esetén minden borvidékre kiszámításra került Hoover-indexek értékeit a 4. ábra tartalmazza.

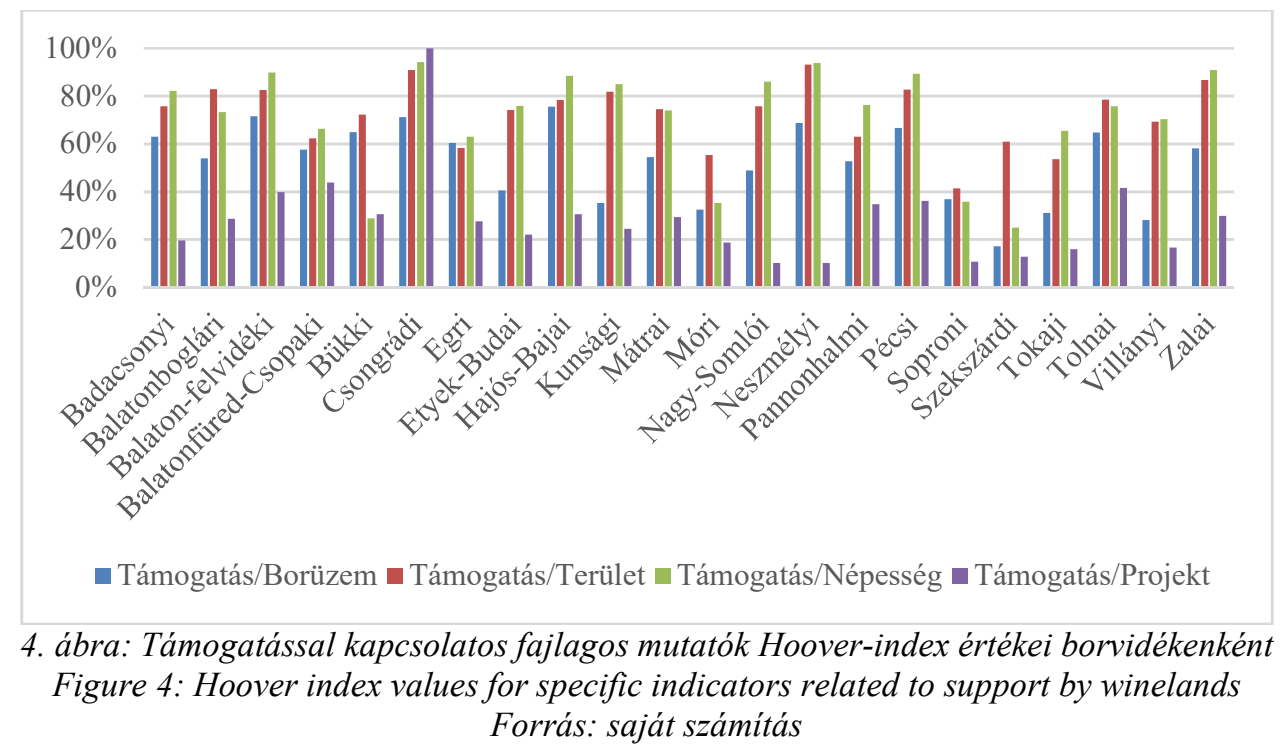

Az egyenlőtlenségi mutatók összefüggésvizsgálatának eredményeként mindegyik esetében elfogadásra került a nullhipotézis.

A borászati üzemekre jutó támogatások esetén a legkisebb egyenlőtlenség a Szekszárdi $(\mathrm{H}=17,1 \%)$, a Villányi $(\mathrm{H}=28,07 \%)$, és a Tokaji $(\mathrm{H}=30,98 \%)$ borvidékeken volt, míg a legnagyobb a Hajós-Bajai $(75,48 \%)$, Balaton-felvidéki $(\mathrm{H}=71,44 \%)$, és a Csongrádi $(\mathrm{H}=71,11 \%)$ borvidékeken jelentkezett. A borvidékek összes bruttó területére jutó támogatásoknál nagyfokú egyenlőtlenségröl beszélhetünk az összes borvidék tekintetében, hiszen a H érték minimumával rendelkező Soproni borvidéknél is magas, 41,27\%-os értéket figyelhetőnk meg, és 14 borvidéknél az érték meghaladja a 70\%-ot. Hasonló egyenlőtlenség jelentkezett a lakosságszámra jutó támogatások esetén is, ahol 15 borvidéknél találhatunk 70\%-nál magasabb értéket. E tekintetben a legkiegyenlítettebb borvidék a Szekszárdi és a Bükki, ahol H=24,98\%, illetve 28,86\%.

A támogatási összegek települési szintü adatainak területi autokorrelációs vizsgálati eredménye $(\mathrm{G}=0,022427, \mathrm{Z}=12,964, \mathrm{p}=0)$ alapján a támogatási összegek területi megoszlása tekintetében elvetettem a nullhipotézist. A vizsgált változó térbeli csoportosulásait az 5. ábra szemlélteti. 


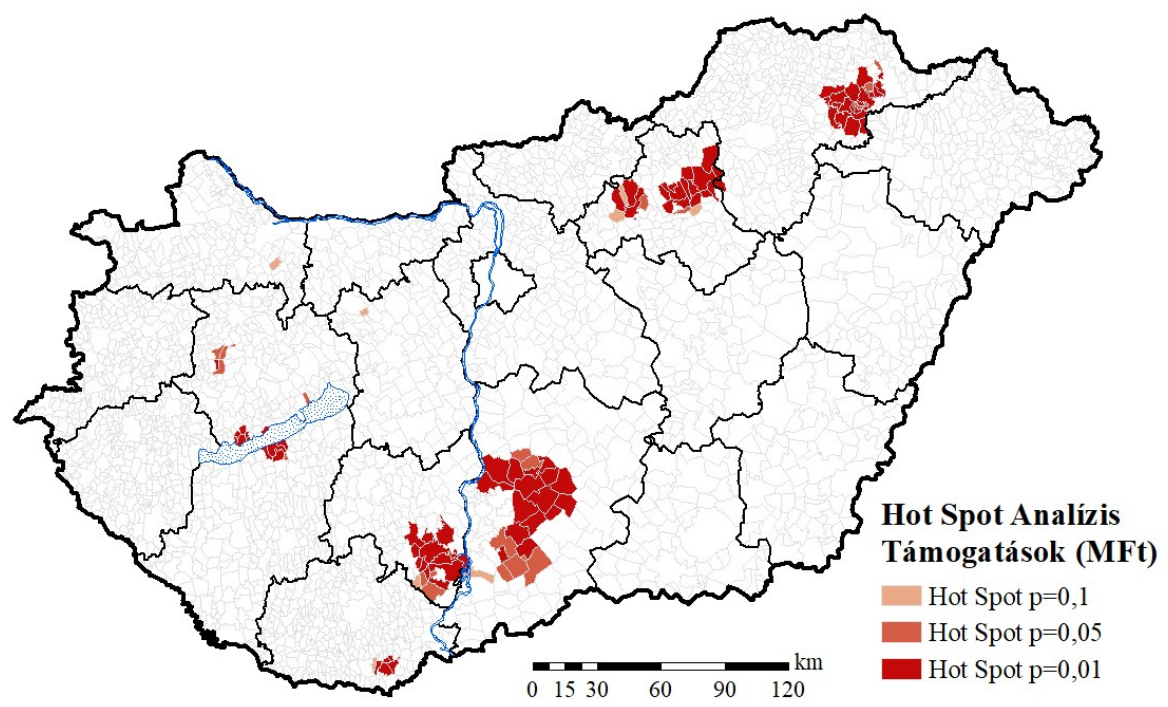

5. ábra: Településenként aggregált támogatások hotspot analízise

Figure 5: Hotspot analysis of aggregate subsidies by settlement Forrás: saját számitás és szerkesztés

Összességében 15 borvidéken találhatóak hotspottal érintett települések, ebből 13 borvidéken vannak legalább $\mathrm{p}=0,05$ szignifikanciaszint mellett eredmények. Jelentős támogatási hotspot területek találhatók az Észak-Magyarországi régióban a Tokaji-, az Egri-, és a Mátrai borvidéken, illetve az Alföld területén a Kunsági borvidéken, valamint a Dél-Dunántúli régióban a Szekszárdi, és Villányi borvidékeken. Kisebb hotspot-területek detektálhatók a Balaton borrégió több borvidékén, valamint a Pannonhalmi-, és Móri borvidékeken.

Mindösszesen 108, az összes borvidéki település 17,28\%-a tartozik hotspot területek alá, és ezekre a településekre érkezett az összes vizsgált támogatás 74,29\%-a. Ezeknek a településeknek az összes bruttó területe $4108,4 \mathrm{~km}^{2}$, az összes bruttó borvidéki terület 16,17\%-a. A hotspot települések lakónépesége 320925 fövel az összes borvidéki településen élők 11,66\%-át adják. Az itt nyertes projektek az összes ezeken a területeken bor-előállítással foglalkozó borászati üzemszám 23,67\%-a, ami csak másfél százalékponttal magasabb az országos, 22,31\%-os értéknél. Az Észak-Magyarországi régióban található hotspotok közül a Tokaji fejlesztési hotspot a borvidék összes településének $81,5 \%$-ra terjed ki, és a borvidék bruttó területének $65,6 \%$-át fedi le, ahol a borvidék lakosságának 54,31\%-a él. Az Egri hotspot települési viszonylatban a borvidéki települések 78,95\%-át érinti, a borvidéki bruttó területből 85,68\%-kal részesedik azzal, hogy ezeken a területeken él a borvidék lakosságának 93,55\%-a. A mátrai hotspot lényegesen kisebb két északi társánál, tulajdonképpen Gyöngyös városára, és annak szoros vonzáskörzetében található 7 településre terjed ki. A hotspot területe a Mátrai borvidék bruttó területének $24,82 \%$ át adja, ahol a borvidék lakóinak 21,69\%-a él.

Az alföldi és dél-dunántúli hotspotok közül a Kunsági borvidéken található az ország legnagyobb területü hotspotja a maga 1291,68 km²-es kiterjedésével lefedi a Kiskőrösi járást. Mérete részben a terület településhálózati sajátosságaiból fakad. A kunsági hotspot arányait tekintve azonban közel sem a legnagyobb, hiszen a borvidéki települések mindössze 15,32\%-át, a bruttó borvidéki terület 15,66\%-át, míg a borvidéken élők mindössze 8,78\%-át érinti. Ezzel szemben Szekszárdi borvidéken található hotspot-terület a borvidéki települések 73,33\%-át érintve fedi le a bruttó borvidéki terület $80,59 \%$-át, és a lakónépesség 93,12\%-át. A villányi és a Balaton borrégiós hotspotok minden viszonyszám tekintetében $30 \%$ alatt maradnak.

A települési szinten egy före jutó támogatások autokorrelációs vizsgálatának eredménye $(\mathrm{G}=0,022818, \mathrm{Z}=12,587, \mathrm{p}=0)$ alapján a vizsgált fajlagos mutató esetén is elvetettem a 
nullhipotézist. E mutató tekintetében a hotspotok dozimetrikus kiterjedése és száma részben eltérő képet mutat a támogatási összegek alapján elvégzett vizsgálat eredményeihez képest (6. ábra).

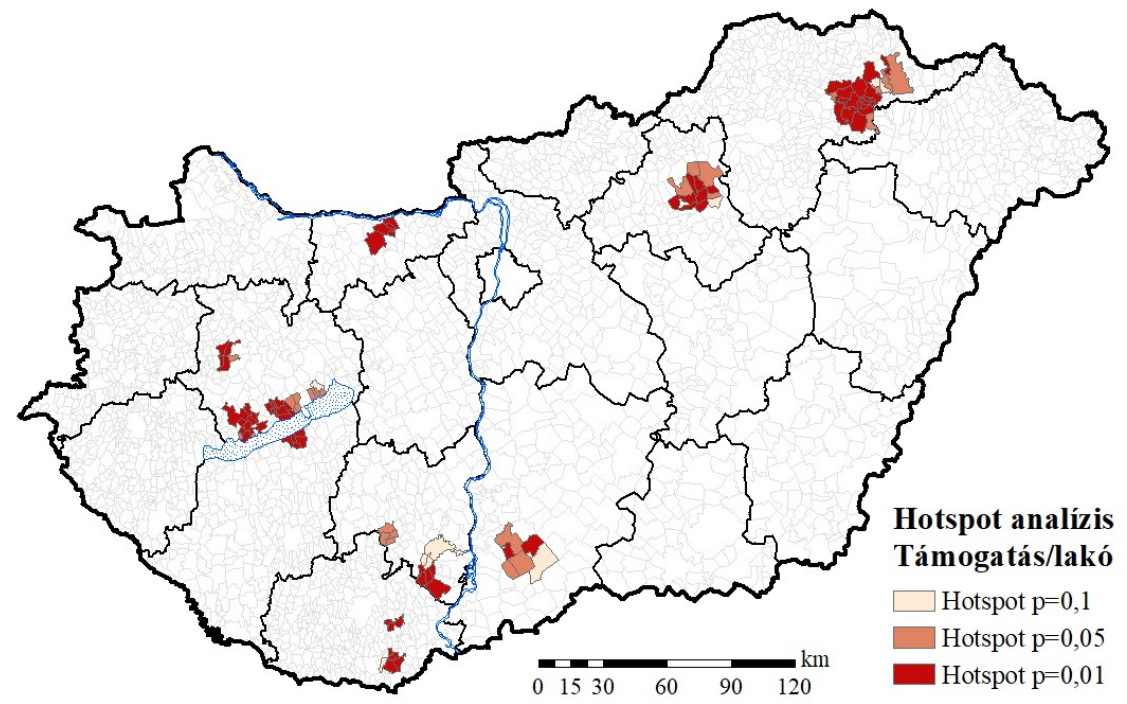

6. ábra: A településenként egy lakosra jutó átlagos támogatások összegének Hot Spot analizise

Figure 6: Hot Spot analysis of the average amount of subsidies per capita per settlement

Forrás: saját számitás és szerkesztés

A hotspotok mindösszesen 107 borvidéki településre terjednek ki, melyből 40 település a Balaton borrégióban található, és azon belül a legtöbb a Balaton északi partján lévő Balatonfüred-Csopaki$(18 \mathrm{db})$, és a Badacsonyi borvidéken $(9 \mathrm{db})$.

Az északi országrészen a Tokaji borvidéken 23 település érintett, tehát több település, mint a nyers támogatási összegek autokorrelációs eredménye által érintett település, és szinte az egész borvidékre kiterjed, csupán négy borvidéki település nem sorolható a forrópont alá. A borvidék lakónépességének 71,42\%-a él ezen hotspot-területeken. Az Észak-Magyarországi régió másik két borvidékéböl a Mátrai borvidéken nem jelentkezett hotspot terület, míg az Egri borvidéken igen, de a támogatási összegek hotspotjához képest enyhén beszükülve, mindösszesen 12 településre kiterjedve a borvidék lakónépességének 85,39\%-át érintve.

A támogatási összegek vizsgálatához képest Komárom-Esztergom megye területén a Neszmélyi borvidéken jelent meg magas szignifikanciaszint $(\mathrm{p}=0,01)$ mellet kisebb forrópont 4 településre és 27427 före kiterjedve.

A Kunsági-, és a Szekszárdi borvidéken a támogatási forrópontokhoz képest a fajlagos mutató hotspotjai erősen beszükültek, és az eredmények szignifikanciaszintje is alacsonyabb valószínüségi tartományban ( $\mathrm{p}=0,1)$ vált értelmezhetővé.

\section{Következtetések}

A számított adatok alapján az EU 2014-2020 programozási időszaka alatt borászati üzemfejlesztési támogatások tekintetében Magyarország három téregységre különült: egy Északiközéphegységi, egy Dél-Dunamenti, valamint egy Észak-balatoni fejlesztési zónára. A támogatások volumene és allokációja tekintetében országos viszonylatban jelentős egyenlőtlenségek figyelhetők meg.

Az Északi-középhegységi fejlesztési zóna az Észak-Magyarországi régióban található három borvidékre terjedt ki, a Tokaji borvidékre, az Egri borvidékre, és a Mátrai borvidékre azzal, hogy az ugyancsak itt található Bükki borvidék e relációban nem érintett. A zóna borvidékeinek egyenlőtlenségi indexei, és a területi autokorrelációs eredmények térbeli mintázata alapján arra a 
következtetésre juthatunk, hogy itt a borászati szakágazati támogatások legnagyobb társadalmi hatása a Tokaji borvidék és Egri borvidék területein jelentkezhetnek, hiszen ezeken a területeken viszonylag nagy lefedettségü, koncentrált térstruktúra került kimutatásra a vizsgált támogatások és fajlagos mutatói tekintetében. A Mátrai borvidékre jutó támogatások viszont annak társadalmi és borászati térszerkezete okán sokkal inkább szakágazati szempontból relevánsak. Ez azonban hosszú távon lehetőséget biztosíthat a szektor társadalmi és gazdasági folyamatokba való tartós beágyazódásához.

A Balaton borrégió támogatási szempontból kettészakadt a Balaton horizontális középvonala mentén. Borászati szakmai szempontból az Észak-Balatoni fejlesztési zóna megjelenése hosszú távon erős versenyhelyzetet teremthet a Balaton borrégió Balatontól távolabb eső, valamint a Balaton déli részén található borrégiós borászatok között. Megjegyzendő, hogy bár a tó déli fele is érintett a támogatások koncentrált megjelenésében, ennek területi kiterjedése és társadalmi hozadéka lényegesen kisebb az ellentétes oldalon megfigyelhetőeknél. Mindemellett a borkibocsájtásra jutó támogatás is sokkal jelentősebb az északi területegységen mint a délin, hiszen előbbi összes borvidéke e mutatószám esetén átlagon felül, míg a déli Balatonboglári borvidék átlagon alul teljesített.

A Dél-Dunamenti fejlesztési zónába irányult nagyarányú támogatás társadalmi hozadékai a számított adatok szerint leginkább a Szekszárdi borvidéken érvényesülhetnek, míg a Villányi borvidéken erős koncentráció mellett, lokális szinten fejthetik ki hatásukat. A Kunsági borvidékre jutó támogatások jelentős térbeli kiterjedéssel jelennek meg, lakosságarányosan viszont koncentráltan jelennek meg a tematikus kartogramokon, ebböl következtethetünk arra, hogy az ide befolyt támogatások lokálisan, helyi szinten fejtik ki hatásukat.

Összefoglalóan megállapítható, hogy a borászati üzemfejlesztési támogatások az Egri- és Tokaji borvidékeken, valamint az Észak-Balatoni téregységben zonálisan, a társadalomba beágyazódva, míg egyéb esetekben jellemzően lokálisan, mikrotérségi szinten jelentkeznek, és helyi ágazatfejlesztési koncepcióként értelmezhetők. Mindazonáltal a támogatások allokációjának térszerkezetéből arra következtethetünk, hogy erősíteni látszanak a borászati ágazat centrumperiféria viszonyainak elmélyülését úgy borvidéki, mint borrégiós területi szinteken egyaránt. Ennek okán hosszú távon a borvidékek periféria-területei jelentős versenyhátrány elé nézhetnek, megnehezítve a területi együttmüködésekböl származó előnyök realizálását.

\section{Irodalomjegyzék}

ÁCS P. - LACZKÓ T. (2008): Területi különbségek a hazai egészségturizmus kínálatában. In: Területi Statisztika 11: 3 pp. 344-357

ENYEDI GY. (2004): Regionális folyamatok a posztszocialista Magyarországon. In: Magyar Tudomány 49. pp. 935-941

GÁL L. (2006): Az Egri Bikavér minőségfejlesztésének lehetőségei. PhD értekezés. Budapesti Corvinus Egyetem. 133 p.

GÁL P. (2020): A borárakat meghatározó tényezők Magyarországon, különös tekintettel a földrajzi árujelzőkre. Doktori értekezés, Budapesti Corvinus Egyetem, Gazdálkodástani Doktori Iskola. 230 p. https://doi.org/10.14267/phd.2020022

GÁL P. (2020): A földrajzi árujelzők szerepe a magyar borpiacon. Statisztikai szemle 98: 3 pp. 242-267., 26 p. https://doi.org/10.20311/stat2020.3.hu0242

GETIS-J. K. - GETIS A. (1996): Local Spatial Autocorrelation Statistics: Distributional Issues and an Application. Geographical Analysis. Vol. 27. No. 4. DOI: https://doi.org/10.1111/j.1538-4632.1995.tb00912.x

GYŐRI T. - EGRI Z. (2020): A munkanélküliek - mint potenciális munkaerő-tartalék térszerkezetének vizsgálata Békés megyében. In: Studia Mundi - Economica 7:2, pp. 217, 15 p. https://doi.org/10.18531/Studia.Mundi.2020.07.02.2-17 
HAJDÚ D. (2021): Európai Uniós forrásból támogatott munkaerő-piaci képzések területi eloszlása Borsod-Abaúj-Zemplén megyében. In: Studia Mundi - Economica 8:1, pp. 2436., $13 \mathrm{p}$.

JÁRDÁNY K. - DURAY B. (2020): Új módszer a magyarországi szőlő-bor termékpályák digitális leképezési lehetőségére. In: Studia Mundi - Economica 7:2, pp. 18-30., 13 p. https://doi.org/10.18531/Studia.Mundi.2020.07.02.18-30

JUHÁSZ B. (2020): A Vajdasági Gazdaságfejlesztési Program előzményei, megvalósulása és eredményei. In: Studia Mundi - Economica 7:1, pp. 12-25, 13 p.

KESZTHELYI K. (2019): Az Új Magyarország Vidékfejlesztési Program területi hatásai. In: Studia Mundi - Economica 6:3, pp. 29-41., 13 p.

KISPÁL G. (2017): Examination of adapting the contractual system in the Hungarian wine sector. Annals of the polish association of agricultural and agribusiness economists 19: $2 \mathrm{pp}$. 108-113., 6 p. https://doi.org/10.22004/ag.econ.293501

KISS J. P. - NÉMETH N. (2006): Fejlettség és egyenlőtlenségek - Magyarország megyéinek és kistérségeinek esete. In: Magyar Tudományos Akadémia Közgazdaságtudományi Intézet, Budapest. 40. p.

LOSONCZ M. (2004): Európai Uniós kihívások és magyar válaszok. Osiris Kiadó. Budapest.

LÖRINCZ M. (2016): A felsőoktatási intézmények regionális beágyazottsága az Északmagyarországi régióban. Doktori értekezés. Debreceni Egyetem Kerpely Kálmán Doktori Iskola Regionális Tudományok Program. Debrecen. $163 \mathrm{p}$.

MAGDA S. - GERGELY S. (2004): A mátrai borvidék szőlő-bor vertikumának fejlesztési stratégiája. In: Gazdálkodás XLVIII. évfolyam 11. számú különkiadása pp. 4.

MELONI, G. - SWINNEN, J. (2013): The Political Economy of European Wine Regulations. Journal of Wine Economics, 8(3): 244-284. https://doi.org/10.1017/jwe.2013.33

MOLNÁR E. (2007): A szekszárdi és a villányi borvidék összehasonlító marketingelemzése. $\mathrm{PhD}$ értekezés. Kaposvári Egyetem Gazdaságtudományi Kar Marketing és Kereskedelem Tanszék, Kaposvár. 206 p.

NEMES NAGY J. (2005): Regionális elemzési módszerek. ELTE TTK Regionális Földrajzi Tanszék, MTA-ELTE Regionális Tudományi Kutatócsoport, Budapest, 284 p.

NEMES NAGY J. (2009): Terek, helyek, régiók: A regionális tudomány alapjai. Akadémiai Kiadó, Budapest. 350p,

SIDLOVITS D. (2008): Vertikális koordináció a szőlő- és borágazatban. PhD értekezés, Budapesti Corvinus Egyetem Interdiszciplináris Doktori Iskola, Budapest. 163 p.

STARK A. (2004): A magyar államháztartás rendszere, müködése, a nemzetgazdasággal való összefüggése. Debreceni Egyetem, Budapest - Debrecen.

TÓTH G. (2014): Térinformatika a gyakorlatban közgazdászoknak. Miskolci Egyetemi Kiadó, Miskolc. 107. p.

TÓTH T. - KÁPOSZTA J. (2014): Tervezési módszerek és eljárások a vidékfejlesztésben (gyakorlat) Gödöllö, Magyarország: Szent István Egyetemi Kiadó, 115 p 